\title{
Sanitary conditions of lactating dromedary she-camel environment with special reference to milk quality and subclinical mastitis monitoring
}

\author{
Saber Kotb $^{1}$, Mohammed Sayed ${ }^{2 *}$ and Ahmed Abdel-Rady ${ }^{3}$ \\ ${ }^{1}$ Department of Animal Hygiene, Faculty of Veterinary Medicine, Assiut University, Egypt; \\ ${ }^{2}$ Department of Food Hygiene, Faculty of Veterinary Medicine, Assiut University, Egypt; \\ ${ }^{3}$ Department of Animal Medicine, Faculty of Veterinary Medicine, Assiut University, Egypt
}

\begin{abstract}
The present study was concerned with 42 dwellings of lactating dromedary she-camels in owner's houses which distributed in 6 different villages around Assiut city, Egypt; to be representative to camel distribution in villages of Manfalout, El-kousia, El-Fateh, Abnob, Abo-Tig and Sedfa. This study was unlike most studies that deal with camels in the nomadic life while here all animals were traditionally managed and were housed in each dwelling. The environmental conditions around animals were estimated microbiologically to evaluate the hygiene of their habitat and to estimate milk quality and also to monitor subclinical mastitis. Therefore, different random samples of air, soil, water, milkers' hands, milk equipments, composite milk and bulk milk samples were collected. It was found wide varieties of a total 599 of pathogenic and potentially pathogenic isolates could be detected and identified in which soil samples had the highest number as 208, while composite milk samples had the lowest as 20 . As the milk was subjected to the surrounding environment, the isolates were elevated to 113 as explained by the significance correlation of total bacterial count between bulk milk and soil. Although all animals were observed as clinically healthy with apparently normal udder, the CMT showed $9.52 \%$ was positive for subclinical mastitis.
\end{abstract}

Keywords: Sanitary conditions, lactating dromedary she-camels, camel milk, milk quality, subclinical mastitis.

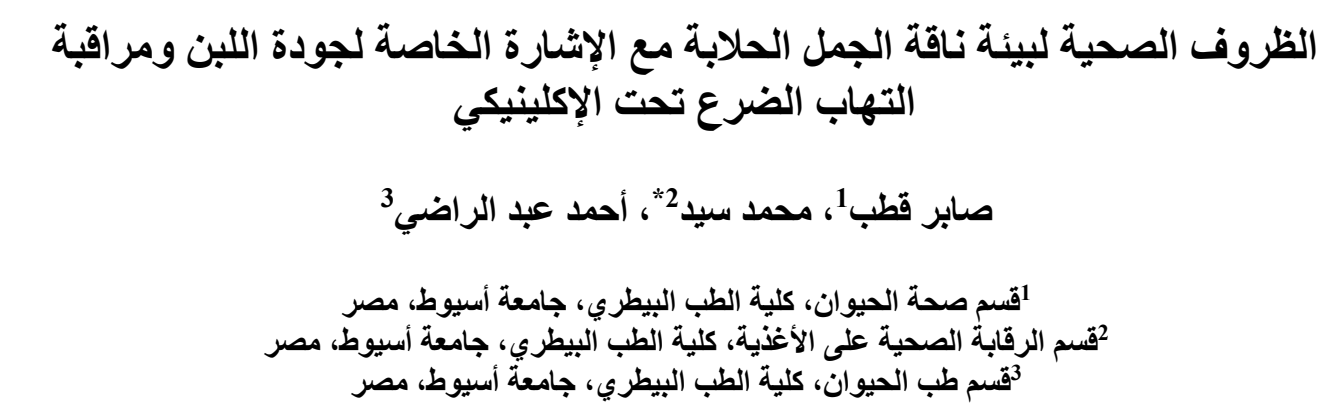

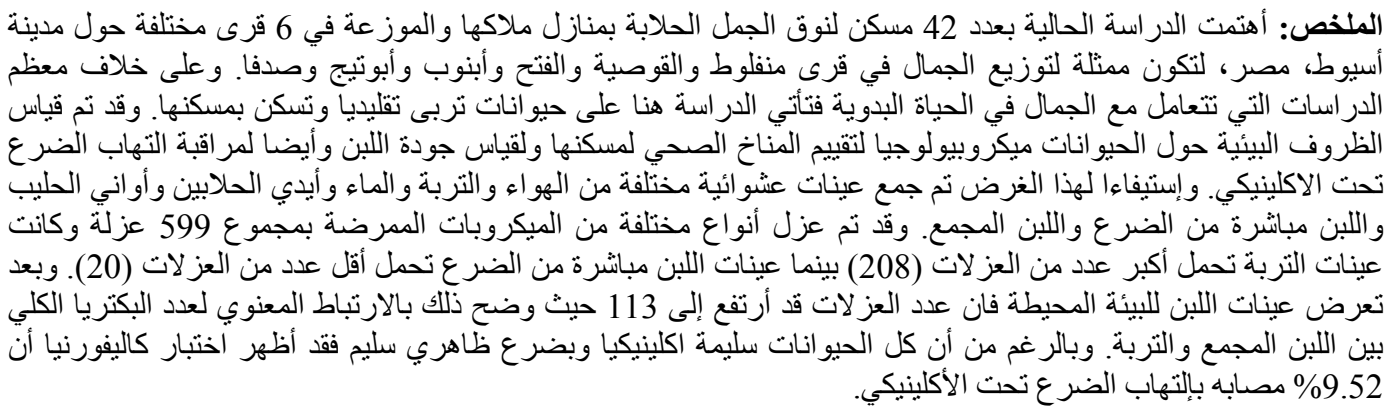

* Corresponding Author, Email: dr.mohammedsayed@yahoo.com 


\section{Introduction}

The environment surrounding animals constitutes the main source of pathogenic and potentially pathogenic micro organisms. Such organisms involved the causative agents of milk deterioration and/or mastitis. The primary entry points of pathogens in milk are animals, milk handlers, milk equipments and other contact environmental sources. Cross contamination of milk can occur from the poor hygiene of milking environment in animal enclosures. Environmental conditions can markedly influence the diseases that may be higher if large numbers of animals are allowed to house in unhygienic conditions (Quigley et al., 1995)

Mastitis is a relatively infrequent disease in Camelidae compared with cattle. There are few data concerning the aetiology, occurrence of mastitis in Camelidae (Abdel Gadir et al., 2006), and there is no doubt that the environment surrounding animals has an influence on milk quality and/or mastitis infection. So, the microbial concentration in or near environment of teat orifice appear to have the dominant influence on the rate of new mastitis infection (Mein et al., 2004).

According to the aforementioned, there is a need to evaluate the sanitary conditions of camel environment in Assiut governorate, especially the environment of lactating she-camels to estimate milk quality and to monitor subclinical mastitis. Therefore, this study was run on representative distribution of camels in 6 villages around Assiut city.

\section{Materials and Methods}

\section{Animals}

A total of 42 lactating dromedary shecamels were traditionally managed and housed in 42 dwellings (one camel per dwelling) associated with owner's houses in 6 different villages of Assiut governorate, Egypt. The 6 villages were represented as 2 north of Assiut city
(Manfalout and El-kousia), 2 east of Assiut city (El-Fateh and Abnob) and last 2 located south of Assiut city (Abo-Tig and Sedfa). These chosen 6 villages to carry out this study were representative to camel distribution in Assiut governorate. All animals aged from 7 to 11 years and were clinically healthy with apparently normal udder and milked manually.

\section{Samples}

From each dwelling of lactating shecamels, the following samples were collected under complete aseptic conditions for microbiological examination. All samples were kept separately cooled and then transferred directly to the laboratory with a minimum of delay to be immediately examined.

1. Air samples: 42 air samples were collected from inside the examined dwelling using sterile liquid impingers supplied with electric counter vacuum pump. The used technique was described by Cown et al. (1956).

2. Soil samples: 42 soil samples (each 100 $\mathrm{g}$ approximately) were collected from the place on which udder of recumbent animal was resting (Hirsh and Chung Zee, 1999).

3. Water samples: 42 water samples were collected in sterilized glass bottles from water buckets using methods described by APHA (1989).

4. Milkers' hands: 42 swabs were collected from milkers' hands. Each sterile swab was moisten with $10 \mathrm{ml}$ of sterile nutrient broth was rubbed on the skin surface of palm.

5. Milk equipments: 42 swabs were collected from inner surfaces of milk utensils just prior milking time.

\section{Milk samples}

6.1. Composite milk samples: 42 composite milk samples were taken 
according to recommendation of National Mastitis Council (1999). The teat apices were cleaned and disinfected with a piece of cotton soaked in $70 \%$ ethyl alcohol, then the first stream was discarded, then about $20 \mathrm{ml}$ of milk was aseptically drawn from each quarter into a sterile $250 \mathrm{ml}$ capacity bottle.

6.2. Bulk milk samples: 42 raw bulk milk samples were collected from owner's bottles into sterile $250 \mathrm{ml}$ sampling bottles.

\section{Microbiological examination}

Total bacterial count (TBC), coliforms count (CC) and yeasts and molds count were done according to the technique described by Cruickshank et al. (1980); Carter and Cole (1990). Bacterial \& mycological culture, isolation and identification of the isolated strains on different liquid and solid media were carried out according to Cruickshank et al. (1980); Treagan and Pulliam (1982); Krieg and Holt (1984); Murry et al. (1984); Carter and Cole (1990); Larkin et al. (1991); Fedio and Jackson (1992); Quinn et al. (1994); Pitt and Hocking (1997).

\section{The California mastitis test (CMT)}

CMT was done for incidence of subclinical mastitis (Schalm et al., 1971). Macroscopic examination of the milk streaks was undertaken in strip cups for the presence of abnormal color, consistency, flakes and other abnormalities.

\section{Results and Discussion \\ Microbial contamination}

The occurrence and persistence of the microorganisms in air, wall surfaces, udder $\&$ teat surfaces and milk utensils and equipments have been largely overlooked as a problem in the hygienic condition of milk (Anderson et al., 1999); the obtained results presented in Table 1 showed how extent these surroundings were contaminated with $\mathrm{TBC}, \mathrm{CC}$ and yeasts and molds count.

\section{Type of microbial contaminants}

Wide varieties of a total 599 of pathogenic and potentially pathogenic isolates could be detected and identified as shown in Table 2. It was noticed that soil contained the highest number of isolates 208 $(34.72 \%)$ while composite milk contained the lowest number 20 (3.34\%). Staph. aureus, Staph. epidermidis and E. coli could be isolated from all the examined samples.

\section{Potential link between the contaminants}

It was noticed in Table 2 that the number of isolates was elevated from 20 in composite milk samples towards 113 in bulk milk samples, in which the subjection of composite milk to the microbial contamination existed in the surroundings could elevate the contamination in bulk milk and that can be explained by the significance correlation of TBC (at 0.01 level) between bulk milk and soil (Table 3). Also, a significant correlation of coliforms (at 0.01 level) between milkers' hands and both of composite and bulk milk samples (Table 4). According to the microbial contamination with yeasts and molds, Table 5 showed the significance correlation between bulk milk and milkers' hands (at 0.01 level) and also between bulk milk and water (at 0.05 level).

\section{Milk quality}

As the initial microflora of milk has a marked influence on the keeping quality of raw milk, once the milk comes outside the udder the contamination of various degrees occur mainly from milking handling and from the environmental contamination (Anderson et al., 1999).

The microbial results of the examined camel milk samples were compared with parameters laid down by European Union (EU) Standard Commission (Anonymous, 1992). According to EU standard, any milk sample considered unacceptable for human consumption if $\mathrm{TBC} \geq 1 \times 10^{5} \mathrm{cfu} / \mathrm{ml}, \mathrm{CC}$ $>2 \times 10^{1} \mathrm{cfu} / \mathrm{ml}$ and Staph. aureus $>5 \times 10^{2}$ $\mathrm{cfu} / \mathrm{ml}$. Consequently, our composite milk samples considered acceptable for human consumption (Table 1). 
Table 1. Statistical analytical count of microorganisms in the examined environmental and milk samples $(n=42)$.

\begin{tabular}{|c|c|c|c|c|c|c|c|c|c|}
\hline \multirow{2}{*}{ Samples } & \multicolumn{3}{|l|}{ TBC } & \multicolumn{3}{|l|}{$\mathbf{C C}$} & \multicolumn{3}{|c|}{ Yeasts \& molds count } \\
\hline & Min. & Max. & Mean \pm SE & Min. & Max. & Mean \pm SE & Min. & Max. & Mean \pm SE \\
\hline Air $/ \mathbf{m}^{3}$ & 0 & $19.5 \times 10^{3}$ & $2.1 \times 10^{3} \pm 0.62$ & 0 & $0.85 \times 10^{2}$ & $0.21 \times 10^{2} \pm 0.04$ & 0 & $0.95 \times 10^{3}$ & $0.06 \times 10^{3} \pm 0.03$ \\
\hline Soil /gm & 0 & $570 \times 10^{3}$ & $106.073 \times 10^{3} \pm 24.7$ & 0 & $8.04 \times 10^{2}$ & $1.25 \times 10^{2} \pm 0.28$ & 0 & $1.5 \times 10^{3}$ & $0.25 \times 10^{3} \pm 0.06$ \\
\hline Water /ml & 0 & $540 \times 10^{3}$ & $36.692 \times 10^{3} \pm 17.8$ & 0 & $0.83 \times 10^{2}$ & $0.21 \times 10^{2} \pm 0.03$ & 0 & $0.25 \times 10^{3}$ & $0.43 \times 10^{3} \pm 0.01$ \\
\hline $\begin{array}{l}\text { Milkers' } \\
\text { hands /palm }\end{array}$ & 0 & $2.49 \times 10^{3}$ & $0.68 \times 10^{3} \pm 0.10$ & 0 & $1.7 \times 10^{2}$ & $0.34 \times 10^{2} \pm 0.07$ & 0 & $0.24 \times 10^{3}$ & $0.02 \times 10^{3} \pm 0.09$ \\
\hline $\begin{array}{l}\text { Milk } \\
\text { equipment } \\
/ \mathbf{m}^{2}\end{array}$ & 0 & $2.88 \times 10^{3}$ & $0.72 \times 10^{3} \pm 0.10$ & 0 & $2.5 \times 10^{2}$ & $0.69 \times 10^{2} \pm 0.10$ & 0 & $0.24 \times 10^{3}$ & $0.038 \times 10^{3} \pm 0.01$ \\
\hline $\begin{array}{l}\text { Composite } \\
\text { milk /ml }\end{array}$ & 0 & $0.68 \times 10^{3}$ & $0.17 \times 10^{3} \pm 0.03$ & 0 & $0.14 \times 10^{2}$ & $0.02 \times 10^{2} \pm 0.01$ & 0 & $0.01 \times 10^{3}$ & $0.05 \times 10^{3} \pm 0.03$ \\
\hline $\begin{array}{l}\text { Bulk milk } \\
\text { /ml }\end{array}$ & 0 & $25 \times 10^{3}$ & $7.147 \times 10^{3} \pm 1.16$ & 0 & $3.46 \times 10^{2}$ & $0.87 \times 10^{2} \pm 0.15$ & 0 & $0.5 \times 10^{3}$ & $0.38 \times 10^{3} \pm 0.17$ \\
\hline
\end{tabular}


Table 2. Incidence of the isolated microorganisms from the examined environmental and milk samples $(\mathrm{n}=42)$.

\begin{tabular}{|c|c|c|c|c|c|c|c|c|c|c|c|c|c|c|}
\hline \multirow{2}{*}{$\begin{array}{l}\text { Isolated } \\
\text { microorganisms }\end{array}$} & \multicolumn{2}{|l|}{ Air } & \multicolumn{2}{|l|}{ Soil } & \multicolumn{2}{|c|}{ Water } & \multicolumn{2}{|c|}{$\begin{array}{l}\text { Milkers' } \\
\text { hands }\end{array}$} & \multicolumn{2}{|c|}{$\begin{array}{l}\text { Milk } \\
\text { equipment }\end{array}$} & \multicolumn{2}{|c|}{$\begin{array}{l}\text { Composite } \\
\text { milk }\end{array}$} & \multicolumn{2}{|c|}{ Bulk milk } \\
\hline & No. & $\%$ & No. & $\%$ & No. & $\%$ & No. & $\%$ & No. & $\%$ & No. & $\%$ & No. & $\%$ \\
\hline Staphylococcus aureus & 10 & 23.81 & 19 & 45.24 & 9 & 21.43 & 15 & 35.71 & 16 & 38.09 & 2 & 4.76 & 9 & 21.43 \\
\hline $\begin{array}{l}\text { Staphylococcus } \\
\text { epidermidis }\end{array}$ & 19 & 45.24 & 28 & 66.67 & 13 & 30.95 & 10 & 23.81 & 15 & 35.71 & 6 & 14.29 & 11 & 26.19 \\
\hline Micrococcus species & 16 & 38.09 & 21 & 50.00 & 7 & 16.67 & 0 & 0.00 & 0 & 0.00 & 0 & 0.00 & 7 & 16.67 \\
\hline $\begin{array}{l}\text { Streptococcus } \\
\text { agalactiae }\end{array}$ & 0 & 0.00 & 6 & 14.29 & 0 & 0.00 & 0 & 0.00 & 2 & 4.76 & 0 & 0.00 & 0 & 0.00 \\
\hline $\begin{array}{l}\text { Pseudomonas } \\
\text { aeruginosa }\end{array}$ & 0 & 0.00 & 7 & 16.67 & 2 & 4.76 & 7 & 16.67 & 7 & 16.67 & 1 & 2.38 & 3 & 7.14 \\
\hline Escherichia coli & 7 & 16.67 & 14 & 33.33 & 8 & 19.05 & 9 & 21.43 & 10 & 23.81 & 3 & 7.14 & 8 & 19.05 \\
\hline Providencia species & 0 & 0.00 & 9 & 21.43 & 2 & 4.76 & 0 & 0.00 & 0 & 0.00 & 0 & 0.00 & 3 & 7.14 \\
\hline Serratia species & 0 & 0.00 & 6 & 14.29 & 4 & 9.52 & 2 & 4.76 & 2 & 4.76 & 0 & 0.00 & 7 & 16.67 \\
\hline Proteus species & 6 & 14.29 & 6 & 14.29 & 4 & 9.52 & 2 & 4.76 & 5 & 11.90 & 0 & 0.00 & 3 & 7.14 \\
\hline Listeria species & 0 & 0.00 & 0 & 0.00 & 0 & 0.00 & 0 & 0.00 & 0 & 0.00 & 0 & 0.00 & 0 & 0.00 \\
\hline Yersinea enteroclitica & 0 & 0.00 & 0 & 0.00 & 0 & 0.00 & 0 & 0.00 & 0 & 0.00 & 0 & 0.00 & 0 & 0.00 \\
\hline Aspergillus species & 0 & 0.00 & 29 & 69.05 & 0 & 0.00 & 2 & 4.76 & 2 & 4.76 & 0 & 0.00 & 20 & 47.62 \\
\hline Pencillium species & 0 & 0.00 & 19 & 45.24 & 0 & 0.00 & 2 & 4.76 & 2 & 4.76 & 0 & 0.00 & 14 & 33.33 \\
\hline Total & 64 & & 208 & & 54 & & 61 & & 79 & & 20 & & 113 & \\
\hline
\end{tabular}


Table 3. Correlation matrix of quantitative data measuring TBC of the environmental and milk samples $(n=42)$.

\begin{tabular}{lllllll}
\hline Samples & Bulk milk & Composite milk & Hand & Air & Soil & Water \\
\hline Bulk milk & 1.0000 & & & & & \\
Composite milk & -0.2938 & 1.0000 & & & & \\
Hand & 0.0568 & 0.2004 & 1.0000 & & & \\
Air & -0.1675 & $0.5449 *$ & -0.0068 & 1.0000 & & \\
Soil & $0.6207^{* *}$ & -0.1388 & -0.0937 & -0.1092 & 1.0000 & \\
Water & -0.2316 & 0.4253 & -0.1070 & -0.1334 & -0.0968 & 1.0000 \\
\hline * Significant at 0.05 lev $^{* *}$ Significant at 0.01 level & & & &
\end{tabular}

* Significant at 0.05 level. ** Significant at 0.01 level.

Table 4. Correlation matrix of quantitative data measuring coliforms of the environmental and milk samples $(n=42)$.

\begin{tabular}{lllllll}
\hline Samples & Bulk milk & Composite milk & Hand & Air & Soil & Water \\
\hline Bulk milk & 1.0000 & & & & & \\
Composite milk & 0.3743 & 1.0000 & & & & \\
Hand & $0.6442^{* *}$ & $0.6114^{* *}$ & 1.0000 & & & \\
Air & -0.0318 & -0.0965 & -0.0353 & 1.0000 & & \\
Soil & 0.1934 & -0.1331 & 0.2038 & -0.1332 & 1.0000 & \\
Water & 0.0361 & 0.0692 & 0.0155 & -0.1525 & -0.0792 & 1.0000 \\
\hline
\end{tabular}

** Significant at 0.01 level.

Table 5. Correlation matrix of quantitative data measuring yeasts $\&$ molds of the environmental and milk samples $(n=42)$.

\begin{tabular}{llllll}
\hline Samples & Bulk milk & Hand & Air & Soil & Water \\
\hline Bulk milk & 1.0000 & & & \\
Hand & $0.9509^{* *}$ & 1.0000 & & & \\
Air & 0.2531 & 0.2955 & 1.0000 & & \\
Soil & 0.3532 & 0.3602 & 0.2979 & 1.0000 & \\
Water & $0.5205^{*}$ & $0.5045^{*}$ & 0.3980 & $0.7548^{* *}$ & 1.0000 \\
\hline \multicolumn{4}{r}{ * Significant at 0.05 level. } & ** Significant at 0.01 level. &
\end{tabular}

For more asseveration, the obtained result of $\mathrm{TBC}$ was compared with Indian bacteriological standards of raw milk (Sherikar et al., 2004) and graded as very good. Additionally, the obtained results were lower than those reported by AlMohizea (1994), Younan (2002), Benkerroum et al. (2003) whom found TBC of camel milk as $2.6 \times 10^{5} \mathrm{cfu} / \mathrm{ml}$ in Saudi Arabia, $1 \times 10^{3} \mathrm{cfu} / \mathrm{ml}$ in Kenya, $6.2 \times 10^{7} \mathrm{cfu} / \mathrm{ml}$ in Morocco, respectively. Also, Benkerroum et al. (2003) obtained higher $\mathrm{CC}$ and yeasts \& molds count as $7 \times 10^{6}$ and $3.8 \times 10^{4} \mathrm{cfu} / \mathrm{ml}$, respectively. It could be explained here that the lesser bacterial load may be attributed to health state of animals, less observation of udder lesions without tick infestation on camel udder, in addition to the dry weather.

According to EU standard, the composite milk samples were safe to consume raw. To come into question, is it safe to consume raw camel milk? Before answering this question, it must be referred to the condition stated by Yagil et al. (1994) "If all camels are healthy there is no need for pasteurization". Camel milk can be consumed raw if camels are healthy, their udders are healthy, their milks follow standard and their environmental conditions are hygienic. Therefore, when composite milk samples were subjected to 
exogenous sources of contamination, its good quality turned lower in the form of bulk milk samples and was indicated by increasing mean values of $\mathrm{TBC}, \mathrm{CC}$ and yeasts and molds count.

The evidence of the good quality of composite milk samples that its freedom from species of Micrococcus, Providencia, Serratia, Proteus, Listeria, Aspergillus and Pencillium. Also, Enterococcus fecalis, Strept. agalactiae and Yersinea enteroclitica were not isolated (Table 2). The empirical observation was scientifically substantiated by demonstrating the stronger antimicrobial activity of camel milk as compared to that of other animal species and its ability to inhibit Gram-positive and Gram-negative pathogens of concern to food safety. It must be not forget that the natural antimicrobial factors can only provide a limited protection against specific pathogens and for a short period (Benkerroum et al., 2003), especially when camel milk is produced in less hygienic environmental conditions.

The presence of Enterococcus fecalis in bulk milk samples in $28.57 \%$ (the same percentage revealed from milkers' hands samples) followed its absence in corresponding composite milk samples suggesting post-milking fecal contamination. Enterococci may provide an evidence of marked fecal contamination of human origin as the human feces was shown to be the main ecological niche of this species (Gelsomino et al., 2002). Enterococci are resistant to heat stress and have a good specific competitiveness in environment with complex micro-flora, hence, they can easily adapt to the hot climate. Benkerroum et al. (2003) suggested that Enterococci would be more reliable indicators of fecal contamination than coliforms in camel milk.

\section{Subclinical mastitis monitoring}

Reports of mastitis in traditionally managed camels are on the rise and are likely to increase further as the milk production per individual camel is increased. Two decades ago there was no mention of mastitis problem at herd level; today it is reported from almost all camel rearing countries (Mohammed et al., 2005).

Whereas all the examined she-camels were clinically healthy with normal udder, subclinical mastitis should be monitored. Four out of 42 lactating she-camels $(9.52 \%)$ was positive CMT. Previous studies showed higher percentage of positive CMT in she-camels like $21 \%$ in Rabbari and Raval communities of 11 villages of north Gujarat State of India (Mody et al., 1998), 13.57\% in Central Somalia (Arush et al., 1984), Quandil and Qudar (1984) recorded lower percentage $(6.38 \%)$ in UAE.

The disease is not usually treated in traditionally managed camels and will often take a natural course to chronic resulting in permanent loss of milk production (Obeid et al., 1996). It is therefore cheaper and easier to prevent mastitis by improving hygienic measures than to treat by medication. The cost of the latter includes veterinary fee, cost of medicine and loss of milk production (Abdurahman, 2006).

\section{Conclusion}

It can be concluded from the present study that the contamination of camel milk and consequently the milk quality were influenced by post-milking environmental contaminants rather than by camel infections.

\section{References}

Abdel Gadir, A. E., G. Hildebrandt, J. N. Kleer, B. Molla, M. N. Kyule and M. P. Baumann. 2006. Comparison of California Mastitis Test (CMT), Somatic Cell Count (SCC) and bacteriological examinations for detection of camel (Camelus 
dromedarius) mastitis in Ethiopia. Berl. Munch. Tierarztl. Wochenschr. 119:45-49.

Abdurahman, O. A. Sh. 2006. Udder health and milk quality among camels in the Errer valley of eastern Ethiopia. Livestock Res. Rural Develop. Vol. 18, article \#110. Retrieved from http://www.irrd.org/irrd18/8/abdu18 110.htm

Al-Mohizea, I. S. 1994. Microbial quality of camel's milk in Riyadh markets. Egyptian J. Dairy Sci. 14:469-487.

Anderson, A. M., N. Weiss, F. Rainey and M. S. Salkinoja-Salonen. 1999. Dustborn bacteria in animal sheds, schools and childern'day care centers. J. Appl. Microbiol. 86:622634.

Anonymous. 1992. Council Directive 92/46 EC of 16 June 1992 laying down the health rules for the production and placing on the market of raw milk, heat-treated milk and milk-based products. Official J. Europ. Comm. 368:1178-1207.

APHA. 1989. Standard Methods for examination of water and wastewater. $17^{\text {th }}$ ed. by Clesceri, L.S., Greenberg, A.E. and Trussell, R.R. published by APHA, AWWA and WPCF, USA.

Arush, M. A., C. Valente, M. Compagnucci and H. Hussein. 1984. Studies on the prevalence of mastitis in the dromedary (Camelus dromedarius) in Somalia. Bullettino Scientifica della Facolta di Zootecniue Veterinaria, Universita Nazionale Somalia, 4:99-104.

Benkerroum, N., A. Boughdadi, N. Bennani and K. Hidane. 2003.
Microbiological quality assessment of Moroccan camel's milk and identification of predominating lactic acid bacteria. World J. Microbiol. Biotechnol. 19:645-648.

Carter, G. R. and Jr. R. Cole. 1990. Diagnostic procedures in Veterinary Bacteriology and Mycology. $5^{\text {th }}$ ed. Academic Press. Inc. Harcourt Brace Jovanovich, Publishers.

Cown, W. B., T. W. Kethley and E. L. Fincher. 1956. The critical orifice liquid impinger as sampler for bacteriological aerosols. J. Appl. Microbiol. 5:119-124.

Cruickshank, R., J. P. Duguid and R. H. Swain. 1980. Medical Microbiology. E.L.B.S., $12^{\text {th }}$ ed. E. and S. Livingstone Ltd., Edinburgh and London.

Fedio, W. M. and H. Jackson. 1992. The origin of Listeria monocytogenes in raw milk. Intern. Dairy J. 2:197-208.

Gelsomino, R., M. Vancanneyt, T. M. Cogan, S. Condon and J. Swings. 2002. Source of Enterococci in a farmhouse raw-milk cheese. Appl. Environ. Microbiol. 68:3560-3565.

Hirsh, D. C. and Y. Chung Zee. 1999. Veterinary Microbiology. Blackwell Science, Inc. USA.

Krieg, N. R. and J. C. Holt. 1984. Bergery's Manual of Systemic Bacteriology. Vol. 1, William's and Wilkins Company. Baltimore MD., 2120, USA.

Larkin, L., P. Vasada and H. Marth. 1991. Incidence of Yersinea enteroclitica in raw milk as related to its quality. Milchwissenschaft, 46:500-506. 
Mein, G. A., D. J. Reinmann, N. Schuring and I. Ohnstad. 2004. Milking machine and mastitis risk. A storm in a teat cup. Proc. $43^{\text {rd }}$ annual meeting of Mastitis National Council.

Mody, S. K., P. R. Patel and C. B. Prajapati. 1998. A study on antimicrobial susceptibility of bacteria isolated from the mastitic milk of rural camels in India. In: proceedings of the third annual meeting for animal production under arid conditions. UAE University. P 138.

Mohammed, A., M. Ruiz-Bascaran and B. Abera. 2005. Cross-sectional study of mastitis in camels (Camelus dromedarius) In Somali Region. Southeastern Ethiopia Bull. No. 53. Animal Health and Production in Africa.

Murry, R. G., D. J. Brenner, M. P. Bryant, J. G. Holt, N. R. Kreig, J. M. Moulder, P. H. Norbert, J. T. Staky, S. P. Lapage, L. P. Hans, L. John and C. V. Niven. 1984. Bergery's Manual of Systemic Bacteriology. $8^{\text {th }}$ ed. William's and Wilkins Company. Baltimore.

National Mastitis Council. 1999. Laboratory handbook on bovine mastitis. National Mastitis Council, Madison, WI.

Obeid, A. I., H. O. Bagadi and M. M. Mukhtar. 1996. Mastitis in Camelus dromedarius and the somatic cell content of camels' milk. Res. Vet. Sci. 61:55-58.

Pitt, J. I. and A. D. Hocking. 1997. Fungi and food spoilage. Blackie Academic and Professional press, Chapman and Hall, London. p. 413-455.
Quandil, S. S. and J. Qudar. 1984. Bacteriological study of some cases of mastitis in the dromedary (Camelus dromedarius) in the United Arab Emirates (Preliminary report). Revue-de-Medicine Veterinaire, 135:705-707.

Quigley, J. D., K. R. Martin, D. A. Bemis, L. N. Potgieter, C. R. Reinemeyer, H. H. Dowlen and K. C. Lamar. 1995. Effects of housing and colostrums feeding on serum immunoglobulins, growth and faecal sources of Jersey calves. J. Dairy Sci. 78:893-901.

Quinn, P. J., M. E. Carter, B. K. Markey and G. R. Carter. 1994. Clinical Veterinary Microbiology. Wolfe Publishing, London.

Schalm, O. W., E. Carrol and N. C. Jain. 1971. Bovine mastitis. $1^{\text {st }}$ ed. Lea and Febiger, Philadelphia, USA.

Sherikar, A. T., V. N. Bachhil and D. C. Thapliyal. 2004. Text book of Elements of Veterinary Public Health. Indian Council of Agricultural Research, New Delhi. P 75-120.

Treagan, L. and L. Pulliam. 1982. Medical Microbiology laboratory Procedures, W.B. Saunders Co. PA, USA.

Yagil, R., O. Zagorski, C. van Creveld and A. Saran. 1994. Science and camel's milk production. Chameux et dromedaries, animeaux laitiers. Ed. Saint Marin, G. Expansion Scientifique Francais, Paris. p 75-89.

Younan, M. 2002. Camel milk production and marketing in Kenya and Somalia. The $8^{\text {th }}$ Kenya Camel Forum, 11-15 March 2002, Mile 46, Kajiado, Kenya. 